\title{
Architecture of Academic Libraries in Europe-Bibliography, 1960-1970
}

W easily notices that planning and building libraries in the United States is one of the most popular subjects. Academic libraries occupy a special place in this endeavor. However, as surprising as it may seem, American authors, especially writers of periodical literature on this subject, are quite unconcerned with the latest trends in the field of planning academic libraries in other parts of the world.

This bibliography, although selective, should be of help to those wishing to approach the problem from the broader aspect. Its compiler is convinced that in recent years no other country accomplished more in the field of academic library architecture than the United States. But periodic and thorough perusal of what is being done elsewhere provides important architectural information, especially concerning new design concepts and library planning on limited budgets.

Hopefully, this compilation will not only be justified in terms of its immediate usefulness but will also provide an impetus for further search in the field.

\section{SECTION 1 \\ GENERAL Works}

Association of Technical Institutions and Association of Principles of Technical

Mr. Melnyk is assistant professor of library science, Wilbur Wright Campus, City College of Chicago.
Institutions. Technical College Buildings: Second Interim Report, the College Library. A.T.I. (1962-1963).

Bleton, Jean. "Construction of University Libraries: How to Plan and Revise a Project," UNESCO Bulletin for Libraries (Nov. 1963), 307-15.

Bleton, Jean. "Les salles de lecture générales dans les bibliothèques universitaires: résultats d'une enquête faite par la Commission F.I.A.B. pour la construction et l'équipement des bibliothèques (General reading rooms in university libraries: results of an inquiry made by the FIAB for the construction and equipment of libraries), Libri 13, no.1 (1963), 61-69.

Brawne, Michael. Libraries: Architecture and Equipment (Text also in German). London: Praeger Publishers, 1970.

Fairhurst, Harry. "A New University Prospect; II. Accommodating the Library in the New University." Aslib Proceedings 17 (April 1965), 10711.

Furlong, Norman, ed. Library Practice for Colleges of Education. Library Association, 1966. Chapter 3: Planning, Accommodation and Furnishing, by J. Simmons, p.38-60.

Harrison, John, and Laslett, Peter, eds. The Brasenose Conference on the Automation of Libraries. London: Mansell, 1967.

Hingorani, R. P. "Library Architecture: A Bibliography," Lucknow Librarian 2, no.4 (March 1964), 251-67.

Humphreys, Kenneth William. "Libraries 
in New Universities," International Library Review 2, no.3 (July 1970), 30728.

Kluth, Rolf. "Bibliotheksstruktur und Baustruktur (The structure of the library and the structure of the building)," Zeitschrift für Bibliothekswesen und Bibliographie 12, no.1 (1965), 333.

Library Association. Colleges of Technology and Further Education Subsection. College Libraries: Recommended Standards of Library Provision in Colleges of Technology and Other Establishments of Further Education. Library Association, 1965.

(Library buildings), Architektur und Wohnform 73, no.7 (Oct. 1965), 35195.

"Library Planning and Building: An Annotated Select Bibliography," Library and Information Bulletin (Library Association) 1, no.3 (1967), 69-80.

Liebers, Gerhard. "Tendenzen im Bibliotheksbau: Wissenschaftliche Bibliotheken (Trends in library building: research libraries)," Verband der Bibliotheken des Landes Nordrhein-Westfalen Mitteilungsblatt 19 (March 1969), 15-42.

"(New building abroad)," Architectural Forum 118 (June 1963), 104-05.

Pevsner, Nikolaus. "Libraries: Nutrimentum Spiritus," article in Architectural Review, Oct. 1961, London.

Piasecki, Wladyslaw. "Hlavní tendence vývoje výstavby knihoven $\mathrm{v}$ současne době (Main contemporary trends in library building)," Technicka knihovna 1 (1965), 1-11.

Priest, Gordon. "The Design and Use of a Library," Education Libraries Bulletin 24 (Autumn 1965), 15-24.

Royal Institute of British Architects. Library. Libraries: University and College: A List of Books, Pamphlets and Periodical Articles in the R. I. B. A. Library. R. I. B. A., 1961.

Sauvenier-Goffin, Elisabeth. "Tendances actuelles dans les constructions de bibliothèques universitaires (Current trends in university library construction)," Archives Bibliothèques et Musées de Belgique 33, no.2 (1962), 23543.

Schild, Johannes. "Zur Problematik und Methodik der Planung von Bibliotheksbauten an Universitäten und Hochschulen (On the problems and methodology of planning library buildings at universities and colleges)," Zentralblatt für Bibliothekswesen 83 (Jan. 1969), 16-22.

Schlitt, Gerhard. "Grosraumbüros und grosse Büroräume in Bibliotheken (Landscape offices and large office layouts in libraries)," DFW (Dokumentation Fachbibliothek Werksbïcherei) 18, no.4 (June 1970), 127-30.

Seth, Jan. "Att bygga universitetsbibliotek (Building university libraries)," Biblioteksbladet 55, no.7-8 (1970), 244-47.

Strebl, Laurenz. "Symposium: Moderner Bibliotheksbau (Symposium on modern library building)," Biblos (Austria) 19, no.1 (1970), 19-33.

Stromeyer, Rainald. Europäische Bibliotheksbauten seit 1930. Wiesbaden: Otto Harassowitz, 1962.

Thompson, Anthony. Library Buildings of Britain and Europe; An International Study, with Examples Mainly from Britain and Some from Europe and Overseas. London: Butterworths and Co., 1963.

Tombor, Tibor, "Vállalati és kutatóintezeti müszaki konyvtárak tervezee (Planning of technical libraries in enterprises and research institutes)," OMKDK Módszertani Kiadványok 25 (1966). 186p. (Summaries in English, Russian, and German.)

University Library Buildings (filmstrip). Paris: UNESCO, 1962.

Verhoeff, J. "Trends in Library Building," Libri 15, no.1 (1965), 56-61.

Wierzbicki, Jerzy. "Optymalne rozwia- 
zania architektoniczne wspólczesnych bibliotek wyzszych zakladow naukowych w Evropie (The best layouts of contemporary libraries in higher educational institutions in Europe)," Rocznik Biblioteki Narodowej 3 (1967), 5-28.

\section{SECTION 2 \\ INDIVIDUAL COUNTRIES \\ Austria-General \\ Kroller, Franz. "Neue Erkentnisse des Bibliotheksbaues (New insights into library building)," in Österreichische Bibliothekartag, Admond,-7 Sep- tember, 1968. Vorträge und Kommis- sionssitzungen (Biblios-Schriften) 51, 25-56.}

\section{Austria-Individual Libraries}

University of Innsbruck Library

Stranzinger, Oswald. "Die Bibliotheksorganisation in der Innsbrucker Baufakultät (Organization of the library of the Faculty of Architecture, Innsbruck), Biblos (Austria) 19, no.3 (1970, 20106.

\section{University of Vienna Library}

Dettelmaier, Rudolf. "Die Erweiterungsbauten der Universitätsbibliothek Wien (Building additions of the university library, Vienna)," Biblos 15, no.3 (1966), 182-93.

\section{Finland-General}

Tammerkann, Eeva-Maija. “Tietellisten Kirjastojen Kehittämissuunnitelmia (Development plans for university and research libraries in Finland)," Kirjastolehti 60, no.7 (1967), 213-18.

Wierzbicki, Jerzy. "Biblioteki Universyteckie w Finlandii (University libraries in Finland)," Przegland Biblioteczny 31 (July 1963), 161-67.

Finland-Individual Libraries

Helsinki University Library

Kauppi, Hilkka M. "Teknillisen Korkea- koulum Kirjasto Uusissa Tiloissa (The new building of the Helsinki Technical University Library)," Kirjastolehti 63, no.6 (1970), 192-93.

Sievänen-Allen, Ritva. "Muuan Kirjastosuunnitelma: Lääketieteellinen Keskuskirjasto (The new quarters of the Medical Central Library of the University of Helsinki)," Kirjastolehti 61, no.4 (1968), 126-27.

Törnudd, Elin. "The New Library Building of Helsinki University of Technology," Tidskrift för Dokumentation 26, no.4 (1970), 47-52.

Jyvaskyla Teachers College Library

Raittila, Pekka. "Pedagogiska Högskolans i Jyväskylä Bibliotek (Jyväskylä Teachers College Library)," Nordisk Tidskrift för Bok-och Biblioteksväsen 49, no.3 (1962), 97-107.

\section{France-General}

"Bibliothèques Universitaires (University Libraries)," L'Architecture Française no.251-52 (July-Aug. 1963), 532.

Bleton, Jean. "Les Nouvelles Bibliothèques Universitaires et Municipals Françaises (New university and municipal libraries in France)," Association des Bibliothécaires Français, Bulletin d'Informations 31 (March 1960), 3137.

Ferguson, John. Libraries in France. Shoe String Press, 1970.

Lelievre, Pierre. "Bibliothèques Universitaires D'Aujourd'hui et de Demain (University libraries today and tomorrow)," L'Architecture Française no. 251-52 (July-Aug. 1963), 5-7.

France-Individual Libraries

Bibliothèque de L'Université de Bordeau Guinard, Jacques. "La Nouvelle Section des Sciences de la Bibliothèque de l'Université de Bordeau (The new Science Department at the University Library of Bordeaux)," Bulletin des 
Bibliothèques de France 10 (Aug. 1965), 293-308.

Bibliothèque Universitaire de ClermontFerrand

Archimbaud, Jacques. "La Nouvelle Section de Médicine et de Pharmacie de la Bibliothèque Universitaire de Clermont-Ferrand (New division of medicine and pharmacy at the library of the University of Clermont-Ferrand)," Bulletin des Bibliothèques de France 13 (Dec. 1968), 519-30.

Sart, Marie-Thérèse. "Une Nouvelle Section à la Bibliothèque Universitaire de Clermont-Ferrand (New section of the Clermont-Ferrand University Library)," Bulletin des Bibliothéques de France 12 (May 1967), 191-93.

Bibliothèque Universitaire de Dijon

Barthélémy, Odette. "La Nouvelle Bibliothèque Universitaire de Dijon (New library of the University of Dijon)," Bulletin des Bibliothèques de France 8 (July 1963), 277-85.

Bibliothèque Universitaire de Grenoble

Chauveinc, Marc. "La Section Sciences de la Bibliothèque Universitaire de Saint-Martin-d'Hères (Science department of the University Library of Grenoble)," Bulletin des Bibliothèques de France 14 (April 1969), 139-50.

Kravtchenko, Suzanne. "La Section DroitLettres de la Bibliothèque Universitaire de Grenoble Saint-Martin-d'Hères (Department of law and arts at the University Library of Genoble)," Bulletin des Bibliothèques de France 14 (April 1969), 131-38.

"La Nouvelle Bibliothèque Universitaire de Grenoble (The new university library at Grenoble)," Bulletin des Bibliothèques de France 5 (Jan. 1960), 17-20.

Trainar, Pierre. "La Section Médecine et Pharmacie de la Bibliothèque Universitaire de Grenoble (Department of medicine and pharmacy of the University Library of Grenoble)," Bulletin des Bibliothèques de France 14 (April 1969), 151-56.

Bibliothèque Universitaire de Lyon-laDoua

Rocher, Jean-Louis. "La Bibliothèque Universitaire de Lyon-La-Doua Après Cinq ans de Fonctionnement (The Lyon-La-Doua University Library after five years in use)," Bulletin des Bibliothèques de France 15 (Nov. 1970), 543-73.

Bibliothèque Universitaire de Nancy Thirion, Gérard. "La Nouvelle Section Lettres de la Bibliothèque Universitaire de Nancy (New humanities section of the University Library of Nancy)," Bulletin des Bibliothéques de France 13 (April 1968), 155-63.

Bibliothèque Universitaire d'Orsay

Garnier, Gabriel. "La Nouvelle Bibliothèque Scientifique Universitaire d'Orsay (The new science library at the University of Orsay)," Bulletin des Bibliothèques de France 7 (Dec. 1962), 565-70.

Bibliothèque Universitaire de Poitiers

Giraud, Jeanne. "La Nouvelle Bibliothèque Scientifique Universitaire de Poitiers (New science library at the University of Poitiers)," Bulletin des Bibliothèques de France 9 (Sept.-Oct. 1964), 387-99.

Bibliothèque Universitaire de Reims

Condamin, Jeanne. "La Nouvelle Bibliothèque Scientifique Universitaire de Reims (New science library of the University of Rheims)," Bulletin des Bibliothèques de France 12 (April 1967), 145-53.

Bibliothèque Universitaire de Rennes

Sansen, J. A. "La Nouvelle Bibliothèque Universitaire de Rennes (The new university library at Rennes)," Bulletin des Bibliothèques de France 5 (Dec. 1960), 453-66. 
Bibliothèque Universitaire de Rouen

Laurent, Pierre. "La Bibliothèque Universitaire de Rouen (Rouen University Library)," Bulletin des Bibliothèques de France 10 (July 1965), 261-69.

Bibliothèque Nationale et Universitaire de Strasbourg

Schlumberger, Simone. "La Section de Médecine de la Bibliothèque Nationale et Universitaire de Strasbourg (The Medical Department of the National University Library of Strasbourg)," Bulletin des Bibliothèques de France 10 (Nov. 1965), 375-79.

\section{Germany-General}

Karl, Hans. Die Vorbereitung der Bauplanung von Wissenschaftlichen Bibliotheken in der DDR (Preparation of building plans for research libraries of the German Democratic Republic). Berlin, 1966.

\section{Germany-Individual Libraries}

Bibliothek der Technischen Hochschule, Aachen

Lohse, Gerhart. "Der Aachener Bibliotheksneubau (New library building in Aachen)," Verband der Bibliotheken des Landes Nordrhein-Westfalen Mitteilungsblatt 16 (1 April 1966), 110 12.

Lohse, Gerhart. "Der Neubau der Bibliothek der Technischen Hochschule Aachen (New library building of the Technical University, Aachen)," Zeitschrift für Bibliothekswesen und Bibliographie 14, no.2 (1967), 83-87.

Lohse, Gerhart. "Neubauvorbereitungen für die THB Aachen; ein Bericht (Plans for a new library building for the Technical University in Aachen; a report)," Zeitschrift für Bibliothekswesen und Bibliographie 9, no.1 (1962), 31-42.

\section{Universitätsbibliothek in Bonn}

Burr, Victor. Der Neubau der Universitätsbibliothek Bonn (The new build- ing of the University Library of Bonn)," Biblos 10, no.1 (1961), 1-19.

Burr, Victor. "Die Problematik des Bibliotheksbaus und der Neubau der Bonner Universitätsbibliothek (On the problems of library buildings and the new building of the University Library in Bonn)," Verband der Bibliotheken des Landes Nordrhein-Westfalen Mitteilungsblatt 12 (Oct. 1962), 186-96.

Vago, P., and Bornemann, F. "Die Universitätsbibliothek in Bonn (The University Library at Bonn)," Baukunst und Werkform 15, no.3 (1962), 132 34.

Wenig, Otto. "Die Feierliche Übergabe des Neubaus der Universitätsbibliothek Bonn am 16. Juni 1962 (Official dedication of new library building of the University of Bonn)," Verband der Bibliotheken des Landes Nordrhein-Westfalen Mitteilungsblatt 12 (Oct. 1962), 173-77.

Universitätsbibliothek Bochum

Pflung, Günther, and Adams, Bernhard. Elektronische Datenverarbeitung in der Universitätsbibliothek Bochum (Electronic data processing at the university library at Bochum)," Bochum: Schürmann and Klagges, 1968.

Universitätsbibliothek Giessen

Ostrem, Walter M. "Daring Design for a German Library at the University of Giessen," Wilson Library Bulletin 38 (Jan. 1964), 406-07.

Schawe, Josef. "Die Neue Universitätsbibliothek Giessen; zum Abschluss des Neubaues (New university library in Giessen; on the occasion of the completion of its new building)," Zeitschrift für Bibiothekswesen und Bibliographie 7, no.2 (1960), 127-39.

Universitätsbibliothek und Technische Informationsbibliothek Hannover

Schlitt, Gerhard, and Tehnzen, Jobst. "Universitätsbibliothek und Technische Informationsbibliothek Hannover; Fünf 
Jahre im Neuen Gebäude (University and Technical Libraries in Hannover; Five years' use of the new facilities)," Dokumentation Fachbibliothek Werksbürherei 18 (1969-70), 1-32.

Universitätsbibliothek Marburg

Haenisch, Wolf. "Neubau der Universitätsbibliothek Marburg (New building of the university Library of Marburg)," Zeitschrift für Bibliothekswesen und Bibliographie 15, no.3 (1968), $190-92$.

\section{Great Britain}

Gehani, T. G. "Some Impressions of British Library Buildings and Some Reflections on Our Future Library Buildings," Herald of Library Science 2 (Oct. 1963), 231-36.

"Libraries in the Space Age," Book Collector 16 (Summer 1967), 151-60.

New Library Buildings, 1963-1964: Articles and Reports Reprinted from the Library Association Record for December, 1964. Library Association, 1964.

"Non-public Library Buildings in the U.K.-a Select Bibliography, 19591960," Library Association Record 63 (Feb. 1961), 48-49.

Reynolds, J. D., ed. Library Buildings 1965. Library Association, 1966.

Sidwell, Leslie. "The Planning of Library Buildings," Library Association Record 72 (March 1970), 93-94.

Smith, Denison Langley, and Baxter, Eric George. College Library Administration, in Colleges of Technology, Art, Commerce and Further Education (Chapter 2: Planning and Equipment, p.17-39). Oxford University Press, 1965.

Stockham, Kenneth Alan. "Library Buildings in the 1960 's," Library World 71, no.834 (Dec. 1969), 177-80.

"University Libraries in England: Warwick, Keele, Exeter and the J. B. Morrell Library, York," Library World 68 (March 1967), 239-53.
Great Britain-Individual Libraries

University of Aberdeen Library

Burman, C. R. "Aberdeen University Library: New Science Library," SLA News (Scottish Library Association) 78 (March 1967), 8-10.

University of Birmingham Library

Humphreys, Kenneth William. "Birmingham University Main Library," Library Association Record 63 (1961), 40-41.

University of Durham Library

Pace, George Gaze. "University Library, Durham," Architectural Review 135 (Jan. 1964), 31.

University of Edinburgh Library

Fifoot, E. R. S. "Edinburgh University Library's New Building," SLA News (Scottish Library Association) 83 (Jan. 1968), 11-14.

"Glasgow and Edinburgh University Libraries," Architectural Review 137 (Jan. 1965), 26.

University of Glasgow Library

"Library at Glasgow University," Architects Journal (16 April 1969), 104358.

Imperial College of Science and Technology Library

Currie, Clifford William Herbert. "Planning of the New Library of the Imperial College of Science and Technology," Libri 15, no.1 (1965), 17-22.

Leeds Polytechnic Library

Flint, J. H. "Some Problems of Planning for Optimum Efficiency: Leeds Polytechnic," Library World 71 (May 1970), 334+.

\section{University of London Library}

Gummer, H. Margaret, and Catton, Raymond. "New Periodicals Wing of the University of London Library," Journal of Documentation 17 (June 1961), 96-105. 
Scott, Charles F. "Microforms Reading Room at the University of London Library," MICRODOC 6, no.3 (1967), 65-67.

University of Newcastle-upon-Tyne Library

Mitchell, William Smith. "The University Library, Newcastle-upon-Tyne," Library Association Record 63 (1961), $35-40$.

University of Oxford Library

"Bibliothèque Universitaire à Oxford. Grande-Bretagne," L'Architecture d'Aujourd'hui 32 (June 1961), 27.

University of Reading Library

"Reading University Library's New Building," Library World 65 (June 1964), 411-13.

University of Salford Library

"Salford University Library: Work Begins on Phase One," Library World 70 (July 1969), 193.

University of Sheffield Library

"Bibliotheque Universitaire. Sheffield. Grande-Bretagne," L'Architecture d'Aujourd'hui (Sept. 1960), 136-38.

"Bibliotheque Universitaire de Sheffield (Library of the University of Sheffield)," L'Architecture Française no. 251-52 (July-Aug. 1963), 69-73.

University of Strathclyde Library

Wood, Charles G. "Andersonian Library, the University of Strathclyde: An Account of a New Conception in University Library Provision," Library Association Record 67 (Nov. 1965), 383-87.

University of Sussex Library

"Library of the University of Sussex," Library Association Record 67 (May 1965), 157-62.

Spence, Basil, and others. "Bibliothèque de l'université du Sussex, Grande Bretagne (Sussex University Library, Great Britain)," L'Architecture d'Au- jourd'hui 35 (March 1965), 76-79.

Hungary-Individual Libraries

Milcolc Technical University Library

Prohl, Peter. "Der Bibliotheksneubau der Technischen Universität für Schwerindustrie in Miskolc (The new library building of the Technical University for Heavy Industry at Miskolc)," Zentralblatt für Bibliothekswesen 83, no.3 (March 1969), 145-52.

Ireland-Individual Libraries

Queen's University Library, Belfast

Harvard-Williams, Peter. "New Science Library at Queen's University, Belfast," Library World 71 (March 1970), 263-66.

Trinity College Library, Dublin

Hurst, F. J. E. "Trinity College Library Dublin: Proposed New Library," Library Association Record 63 (1961), 45- 48.

"New Library for Trinity College, Dublin," Library World 69 (Nov. 1967), 132.

“Thoughtful Design Wins Trinity College (Dublin) Competition," Progressive Architecture 42 (Sept. 1961), 67. "Young Architect Wins Dublin Prize," Liaison (Library Association New Sheet) (July 1961), 53.

\section{Netherlands-Individual Libraries}

Amsterdam University Library

Woude, S. van der. "De Nieuwe Universiteitsbibliotheek te Amsterdam (New Amsterdam University Library)," Bibliotheekleven 46 (May 1961), 221-28.

Nijmegen University Library

Kievits, A. P. M. "De Nieuwbouw van de Universiteitsbibliotheek te Nijmegen (The new building at the University Library at Nijmegen)," Bibliotheekleven 50 ( Jan. 1965), 1-10. 


\section{Poland-General}

Piasecki, Wladyslaw. "Das Erste Modular Bibliotheksgebäude in Polen (The first modular library building in Poland)," Zentralblatt für Bibliothekswesen 81 (Sept. 1967), 535-47.

\section{Scandinavia-General}

Harrison, Kenneth Cecil. Libraries in Scandinavia. rev., $2 \mathrm{~d}$ ed. British Book Center, 1970.

Nissen, Harald, "Nye Universitetsbibliotek i Danmark og Sverige: Inntrykk fra en Studiereise (New university libraries in Denmark and Sweden; impressions of a study-tour)," Bok og Bibliotek 35, no.3 (May 1968), 24145.

\section{Sweden-Individual Libraries}

Chalmers University of Technology Library

Hemlin, Krik. "Chalmers Tekniske Högskolas nya Bibliotek (New library of the Chalmers University of Technology)," Tidskrift för Documentation 17, no.5 (1961), 57-60. English trans.: Library World 64 (July 1962), 10-12.
Royal Institute of Technology Library

Bjorkbom, Carl. “Kungl. Tekniska Högskolans Bibliotek i nya Lokaler (Reconstruction of the library of the Royal Institute of Technology)," Nordisk Tidscrift för Bok-och Biblioteksväsen 49, no.2 (1962), 68-78.

Switzerland-Individual Libraries

University of Basle Library

Senn, Otto. "Der Moderne Bibliotheksbau am Beispiel von Basel (Modern library building; the example of Basle)," 39, no.6 (1963), 161-76.

U.S.S.R.-General

Pashchenko, F. N. "Directions and Technical Specifications for the Design of Libraries in Specialized Schools of Higher and Secondary Education in the USSR," Libri 14, no.2 (1964), 13667.

Pashchenko, F. N., and Vinogradov, V. "Design and Construction of Large Libraries in the U.S.S.R.," UNESCO Bulletin for Libraries 24 (Nov. 1970), 309-18. 